EUROPEAN HONORS COUNCIL

Paper

\title{
Assessment of the impact of COVID-19 on honors student learning, institutional connections, and intent to return to campus
}

Evren Celik Wiltse ${ }^{1}$, Michael Gonda ${ }^{2}$, Camille Massmann ${ }^{3}$, Kas Williams ${ }^{4}$, and Rebecca C. Bott-Knutson ${ }^{5}$

1 School of American and Global Studies, South Dakota State University, USA; Evren.Wiltse@sdstate.edu

2 Department of Animal Science, South Dakota State University, USA; Michael.Gonda@sdstate.edu

3 Van D. and Barbara B. Fishback Honors College, South Dakota State University, USA; Camille.Massmann@sdstate.edu

4 Office of Diversity, Inclusion, Equity, \& Access, South Dakota State University, USA; Kas.Williams@sdstate.edu

5 Van D. and Barbara B. Fishback Honors College, South Dakota State University, USA; Rebecca.Bott@sdstate.edu

*Correspondence: Rebecca.Bott@sdstate.edu

Received: 19 June 2020; Accepted: 7 July 2020; Published: 14 July 2020

\begin{abstract}
The COVID-19 pandemic quickly converted classes to an online format in the middle of the academic semester at South Dakota State University (SDSU), USA. Our objectives were 1) to identify factors affecting student learning and connectivity following this transition and 2 ) to evaluate differences between honors and non-honors students. Students $(n=230)$ were surveyed with Likert-type, descriptive, and open-ended questions about their experiences following the transition. Clear, frequent communication between students and SDSU was identified as the most appreciated aspect of SDSU's response. Students who reported struggling academically following the transition were more likely to be facing difficulties with finances and access to or use of online learning technology. Honors students reported fewer technology barriers and financial stressors than non-honors students. Degree completion and social connections were driving the desire to return to face-to-face classes, but this enthusiasm was dampened by COVID-19-related health concerns. Communication, structure, and flexibility were identified as factors affecting student success.
\end{abstract}

Keywords: COVID-19, honors education, online learning, connection 


\section{Introduction}

In the wake of COVID-19, higher education institutions have been faced with unprecedented challenges. In spring of 2020, students, faculty, staff, and their families transitioned to an online environment abruptly and faced negative impacts of transition. Past outbreaks of disease, such as MERS and SARS, brought with them concerns of impacts on financial, mental, and physical health, and quality of teaching and learning in distance environments (Al-Rabiaah et al., 2020). The 2020 COVID-19 pandemic is no exception. Assessment of student perceptions of this pandemic and their ability to pursue academic success while maintaining connections to their institution are valuable in understanding how universities can better prepare for future disruptions.

A growing concern in colleges, especially among honors students, is mental health (Pham, 2017). COVID-19 and the transition to distance education has introduced new and dire concerns. A study of Chinese university students estimated that 25 percent experienced new anxiety resulting from COVID-19 (Zhai \& Du, 2020). Living alone, altered or limited access to counseling and support services, disruption of academic environment, degree completion delays, and family or friends falling ill are all concerns that increase students' risk of developing anxiety disorders (Cao et al., 2020; Zhai \& Du, 2020). Also, many students have experienced cancellations or postponements of internships, jobs, and post-graduation plans. According to crowd-sourced data from Canada, up to 86 percent of students that experienced these cancellations reported worrying about their financial wellbeing (Wall, 2020; Zhai \& Du, 2020).

Distance education is a commonly debated practice in honors education. Under normal circumstances, distance learning is rare in honors education, as it seems to go against common practices of hands-on, interactive, engaging curricula. Supporters of online education assert that quality honors education can be achieved through proper faculty training, planning, and support (Nightingale, 2014; Zubizarreta, 2020). However, the sudden transition to distance education due to COVID-19 was anything but planned. Emergency online teaching came abruptly and left many faculty members without sufficient support, for existing infrastructure was not designed to support full-time online instruction. While typical online courses take six to nine months to plan, the sudden shift was completed in only a few weeks (Hodges, Moore, Lockee, Trust, \& Bond, 2020). Thus, neither faculty nor students had the benefits of structured planning for success in online teaching and learning.

The purpose of the current study was to understand the post-COVID-19 experiences of our students with the intent of using their feedback to refine and improve possible hybrid and online transitions for future courses which are traditionally offered face-to-face. Our objectives were to determine:

1. Factors affecting student learning during COVID-19

2. Whether students continue to feel connected to SDSU

3. Key factors impacting students' decisions to return to campus next year

4. Differences among honors and non-honors students

While the current study is focused on the impact of COVID-19 in honors and in higher education, there are broader implications for understanding student preferences and learning ability in online or rapidly changes formats. Honors education is often touted as 
being nimble and innovative. The results of this study emerged from an opportune moment to collect student insight during a global pandemic and one that caused significant and sudden changes in educational formats. If honors education is to remain relevant, curricula and pedagogies must be nimble in the face of acute change and innovative in designing ongoing positive shifts in higher education.

\section{Methods}

\subsection{Survey design and distribution}

This survey has been adapted with permission from the (c) 2020 Higher Education Data Sharing Consortium (HEDS). HEDS is an independent, not-for-profit consortium of higher education institutions that aims to improve undergraduate education by serving as a platform for shared data and knowledge. They conduct periodic nation-wide surveys on student success, diversity, research practices, and campus climate. By adapting the survey from the HEDS, this project was able to incorporate certain questions that were already tested and utilized at the national level. The research team obtained approval under the SDSU Center for the Enhancement of Teaching and Learning, Scholarship of Teaching and Learning Umbrella IRB (Institutional Review Board). The QuestionPro survey included 22 substantive and five demographic questions (see Appendix A). Among the 22, seven were descriptive, six were open ended, and nine were Likert-type questions. The survey was delivered via email to all 2,023 students enrolled in the Honors College, the School of American and Global Studies, affiliated with the ADA (Americans with Disabilities Act) or multicultural centers, and to those enrolled in one of our TRiO programs. These are federally mandated programs that aim to provide a supportive and welcoming university experience to less advantaged students, including minorities, low-income, and first-generation college students. This distribution allowed us to not rely exclusively upon the honors students. The survey was delivered during the first week of May when final examinations were in session and remained active for three weeks. During this period, 573 students viewed the survey, and, of those, 230 (40 percent) fully completed it, yielding an overall response rate of at least 11.4 percent. The response rate could be higher, since some students belonged to more than one of the targeted groups the survey was sent to, and the list was not vetted for duplicates. SDSU is the largest and most comprehensive land grant university in South Dakota with over 11,500 students from all 50 states and 83 countries pursuing degrees in 82 undergraduate majors, 36 master's programs, and 15 doctoral programs.

\subsection{Quantitative analysis}

Two separate quantitative analyses were completed. In the first analysis, students were placed into one of four categories based on whether they self-reported struggling academically before and after the transition to online classes during the COVID-19 pandemic:

Group 1: Those who struggled before and after COVID transition $(n=13)$

Group 2: Those who struggled only before the COVID transition $(n=6)$

Group 3: Those who struggled only after the COVID transition $(n=99)$

Group 4: Those who did not struggle before or after the COVID transition ( $n=123)$.

The above sample exceeds 230 students who completed the entire survey, because students who did not answer all questions but answered this particular question were included in this analysis. Because of the small sample size for the first two categories, they were not 
analyzed further in this first quantitative analysis only. A t-test statistic was used to compare responses to 41 questions between Group 3 and Group 4 with R software. The number of questions exceeds that reported above because most of the 9 Likert-type questions asked for feedback about more than one factor that could affect a student's experience. For example, one Likert question asked about time spent on different tasks (e.g., studying, working) and each task was treated as a different question in the quantitative analysis. A $P$ value $<0.05$ was our threshold for statistical significance; however, Bonferroni-corrected $P$ values are also reported. In the second analysis, honors $(n=126)$ and non-honors $(n=116)$ students were compared with a t-test as described above. As before, the above sample exceeds 230 students because students who answered this question but did not answer all questions were included in this analysis. Students who reported intent to graduate with honors distinction were categorized as honors students and students who did not were categorized as non-honors students.

\subsection{Coding and thematic analyses}

In this project, the intention was to capture and reflect the student experience as accurately and transparently as possible. Therefore, a significant portion of the survey consisted of open-ended questions. When coding these, an inductive coding approach was implemented (Linneberg \& Korsgaard, 2019). Instead of imposing a priori categories to the answers, phrases directly used by the students were selected. While the initial round of coding created nearly a dozen categories for each question, in the second round, similar categories were clustered together to generate higher level categories that would help with a more parsimonious analysis. In order to strengthen the reliability of our coding, two team members separately coded the data in the first round. Their results were systematically compared before moving on to the second round. Of the six open ended questions, scores of two team members were only two percent to five percent different from each other in the first round. A third team member also coded five percent of the answers for each of the open-ended questions separately, for a second test of reliability. The coding practices and results proved to be consistent among all team members.

Our thematic analysis was adapted from Braun and Clarke's (2006) method with team members openly discussing themes until reaching consensus. Each team member reviewed the open-ended responses independently prior to gathering to discuss results. Team members discussed potential themes, and two members of the team independently coded student responses based on the initial themes and revisited the themes alongside examples of initial coding. Finally, three team members commenced secondary independent coding, with team members identifying key participant quotes. Students who did not make comments in the open-ended questions were removed from the analysis. Coding from three investigators was compared, and, when two or more were in agreement, the average number of posts a student made within a category was calculated. The percentage of honors and non-honors students responding in each category was then calculated.

\section{Results: Quantitative analysis}

The majority of respondents ( 63 percent, $n=126$ ) reported intent to graduate with honors distinction. First-generation college students comprised 18.5 percent $(n=37)$ of our sample. Survey respondents also self-identified as TRiO students ( 8.5 percent, $n=17$ ), living with a disability (7.5 percent, $n=15)$, and student-athletes ( 8 percent, $n=16$ ). Our TRiO programs are 
designed to increase access, preparation, and success of first-generation college and economically disadvantaged students, whereas athletic teams are a component of many US colleges and universities. Percentages exceed 100 percent because students can self-identify with multiple groups.

The majority of respondents self-reported as white (90.75 percent, $n=206)$, with minorities of American Indian or Alaska Native Asian (3.52 percent, $n=8$ ), Black or African American (4.41 percent, $n=10$ ), and Native Hawaiian or Pacific Islander (1.32 percent, $n=3$ ). Eight percent of respondents identified themselves as Hispanic or Latino/a/x $(n=18)$. These demographics are consistent with demographics of South Dakota State University in the 2019-2020 academic year. Seventy-five percent of respondents also self-reported as female $(n=167)$.

Students who reported not struggling academically before the transition to online classes were divided into two categories: 1 ) those who struggled academically after the transition $(n=99)$ and 2$)$ those who did not $(n=123)$. Responses to 22 substantive survey questions were different between these groups $(P<0.05$; Appendix $\mathrm{B})$. Among these, responses to five questions were highly significantly associated with whether students reported struggling academically after transitioning to online classes: faculty care and concern for the student, satisfaction with support received from SDSU during the transition, concern with performance in online classes, worry about paying bills, and ability to participate in live or synchronous class activities because of other obligations (Bonferroni $P<0.0014$ ). Students who reported struggling also reported decreased satisfaction with communication about the transition to online classes, increased difficulties with technology and internet access, and increased worry about basic living necessities (e.g., food, housing). Post-COVID-19 academic struggles were not associated with use of student services or perceptions of whether certain types of instruction were more or less challenging in an online environment, except for perceptions of group work $(P=0.023)$.

The abrupt transition to an online environment resulted in students feeling less connected to campus (Figure 1A). However, the majority of respondents also believed this level of (dis)connection was appropriate given the circumstances (83.56 percent; Figure 1B).

Figure 1: (A) Student reflection on how connected they feel to campus, and (B) level of appropriateness of connection.
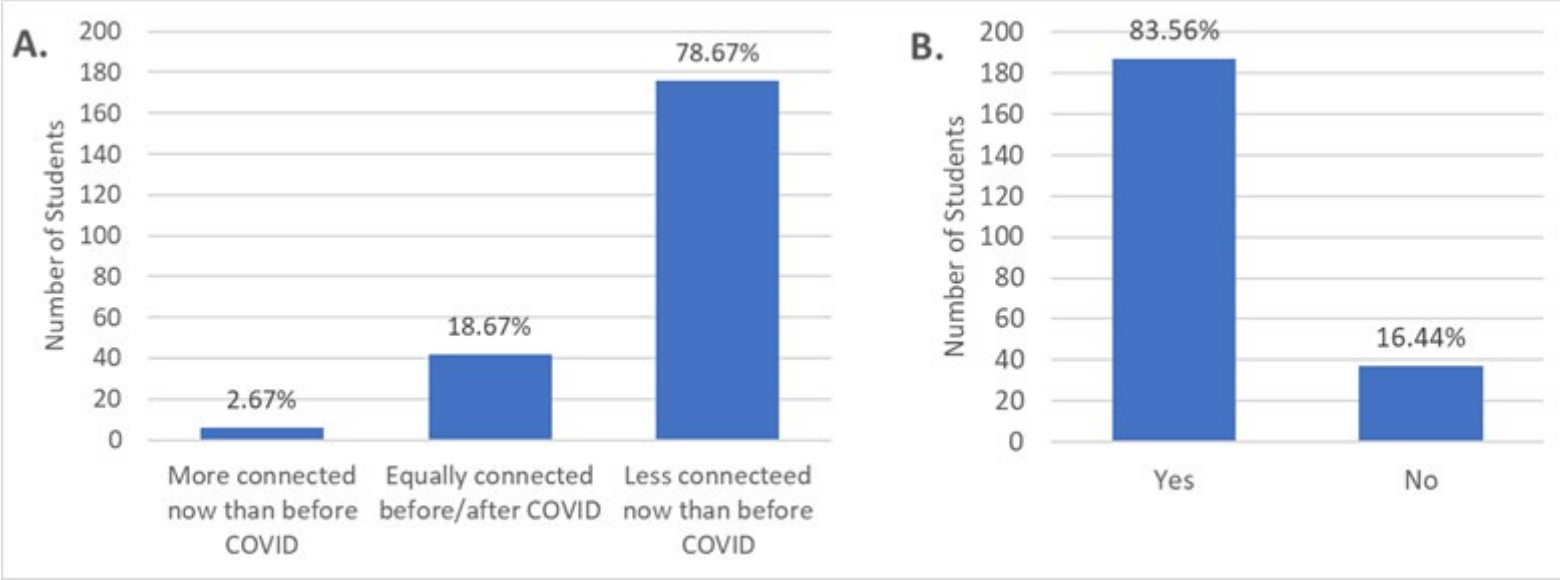

Journal of the European Honors Council 2020, Vol. 4 (1), 9 
Students who reported struggling after the transition to online classes were more likely to believe the level of connection was not appropriate $(P=0.0046)$. Honors students were not more or less likely to believe the level of connection was appropriate than other respondents in the survey $(P=0.473)$.

Responses to 15 questions (seven questions if using the more stringent Bonferroni correction) on the survey were significantly different $(P<0.05)$ between honors and nonhonors students (Table 1 ). Honors students were generally less concerned about economic issues after the transition to online learning, including paying bills, housing, healthcare, and food security. They were also less likely to report technology or accessibility problems. Honors students reported being able to participate in live or synchronous class meetings more often than non-honors students. When asked if students felt 1) more connected, 2) equally connected, or 3 ) less connected after COVID-19, honors students reported feeling less connected (2.82) than non-honors students (2.69) after COVID-19 (t-test = 1.99; $\mathrm{P}=0.0475)$.

Many of the questions where responses differed between honors and non-honors students were the same questions where responses differed between students who reported struggling after transitioning to an online environment as compared to those who did not report struggling after the transition.

Table 1. Comparison of students who self-reported as 1) intending to graduate with Honors distinction ( $n=126)$ and 2$)$ not intending to graduate with Honors distinction ( $n=116)$.

\begin{tabular}{|c|c|c|c|c|}
\hline Honors Students: & $\begin{array}{l}\text { Mean } \\
\text { Honors } \\
\text { Students }\end{array}$ & $\begin{array}{l}\text { Mean Non- } \\
\text { Honors } \\
\text { Students }\end{array}$ & t-test & $P^{1}$ \\
\hline $\begin{array}{l}\text { Believed staff and administration showed } \\
\text { more care and concern }{ }^{2}\end{array}$ & 4.30 & 3.93 & 3.45 & $0.0007^{\dagger}$ \\
\hline $\begin{array}{l}\text { Were less worried about doing well in } \\
\text { college after switching online }{ }^{3}\end{array}$ & 3.06 & 3.44 & 2.48 & 0.0139 \\
\hline $\begin{array}{l}\text { Were less worried about technology } \\
\text { problems }^{3}\end{array}$ & 2.06 & 2.53 & 3.14 & 0.0019 \\
\hline $\begin{array}{l}\text { Were less worried about whether course } \\
\text { materials were in a disability accessible } \\
\text { format }^{3}\end{array}$ & 1.46 & 1.98 & 3.57 & $0.0004^{\dagger}$ \\
\hline $\begin{array}{l}\text { Were less worried about access to health } \\
\text { care }^{3}\end{array}$ & 1.56 & 2.05 & 3.26 & $0.0013^{\dagger}$ \\
\hline Were less worried about paying bills ${ }^{3}$ & 2.27 & 2.86 & 3.40 & $0.0008^{\dagger}$ \\
\hline Were less worried about housing ${ }^{3}$ & 1.25 & 1.64 & 2.64 & 0.009 \\
\hline Were less worried about food insecurity ${ }^{3}$ & 1.29 & 1.77 & 3.31 & $0.0011^{\dagger}$ \\
\hline Were more comfortable using Zoom ${ }^{4}$ & 3.75 & 3.46 & 2.08 & 0.039 \\
\hline $\begin{array}{l}\text { Were less likely to experience problems } \\
\text { with accessibility formats for disabilities }{ }^{3}\end{array}$ & 1.18 & 1.48 & 2.96 & 0.0036 \\
\hline $\begin{array}{l}\text { Were less likely to experience problems } \\
\text { with technology }{ }^{3}\end{array}$ & 1.51 & 1.88 & 2.76 & 0.0064 \\
\hline $\begin{array}{l}\text { Were less likely to experience problems } \\
\text { with sharing technology }{ }^{3}\end{array}$ & 1.40 & 1.67 & 2.10 & 0.0372 \\
\hline
\end{tabular}




\begin{tabular}{|c|c|c|c|c|}
\hline $\begin{array}{l}\text { Were less likely to experience problems } \\
\text { with scanning or printing course } \\
\text { materials }^{3}\end{array}$ & 1.93 & 2.56 & 3.49 & $0.0006^{\dagger}$ \\
\hline $\begin{array}{l}\text { Had fewer problems attending live or } \\
\text { synchronous class meetings }{ }^{3}\end{array}$ & 2.15 & 2.55 & 2.50 & $0.0134^{\dagger}$ \\
\hline \multicolumn{5}{|c|}{$\begin{array}{l}{ }^{1} \text { Only responses exceeding nominal significance level of } \mathrm{P}<0.05 \text { reported; }+=\text { Bonferroni } \mathrm{P}<0.0014(\mathrm{n}=37) \text {. } \\
{ }^{2} \text { Responses coded as } 1=\text { strongly disagree, } 2=\text { disagree, } 3=\text { neutral, } 4=\text { agree, and } 5=\text { strongly agree. } \\
{ }^{3} \text { Responses coded as } 1=\text { never, } 2=\text { once in a while, } 3=\text { about half the time, } 4=\text { most of the time, and } 5= \\
\text { always. } \\
{ }^{4} \text { Responses coded as } 1=\text { very uncomfortable, } 2=\text { uncomfortable, } 3=\text { neutral, } 4=\text { comfortable, and } 5=\text { very } \\
\text { comfortable. }\end{array}$} \\
\hline
\end{tabular}

\section{Results: Qualitative analysis}

The first and overarching theme of teaching and learning stood out in student comments, likely due to the nature of the open-ended questions. Access to and preferences for technology were common, as were those related to health and safety. The final theme was the social and economic impacts of COVID-19. Multiple themes were often addressed in a single response, indicating that the intersectionality of these themes during COVID-19 could either enhance or detract from student success. Thirty students who did not respond to open-ended questions were excluded from qualitative and thematic analyses.

\subsection{Teaching and learning via technology in the COVID-19 era}

Hallmarks of effective teaching and learning prior to COVID-19, such as strong and timely communication, clear organizational structure and expectations, and accommodation of multiple learning styles, continued to resonate for students during the transition. Active learning supplements to recorded lectures were appreciated, provided they did not make undue additions to the pre-COVID-19 workload. Students recognized when instructors were willing to adapt their approaches to meet student needs, including additional or flexible office hours. One student commented, "[To] those that have made necessary changes - given more time during exams, extra help sessions, etc. THANK YOU." Another said, "This has been hell as someone who avoids online courses like the plague, but my professors have really pulled out all the stops to make it work."

Synchronous Zoom lectures were both the most and the least favored instructional method (Figure 2). They provided real-time access to professors and peers, timely feedback to questions, as well as a sense of community and weekly structure. However, for a significant portion of the students, obligations such as work or sibling care made synchronous lectures less convenient. This second group appreciated asynchronous formats due to their flexibility and accommodating nature. Clear preference was expressed for shorter lectures with plenty of visuals over long lectures without much visual stimuli. Shorter recorded lectures "worked much better for learning the material because I could spread out studying which increased my retention of the material."

Laboratories, clinicals and other hands on experiences did not work well after the COVID-19 transition; pre-existing problems were exacerbated, and new problems arose. Numerous comments addressed frustration surrounding learning laboratory techniques online, stating it was no longer "the real experience." This quote sums up the student sentiment: "I don't 
think reading about the labs I was supposed to perform was effective as interpreting the results did not allow for me to understand the test and how it is performed."

Figure 2: Student reports on instructional methods (delivery, technology, assignments, and communication from faculty) that worked the best post-COVID transition (blue bars) and those that did not work well (yellow bars).

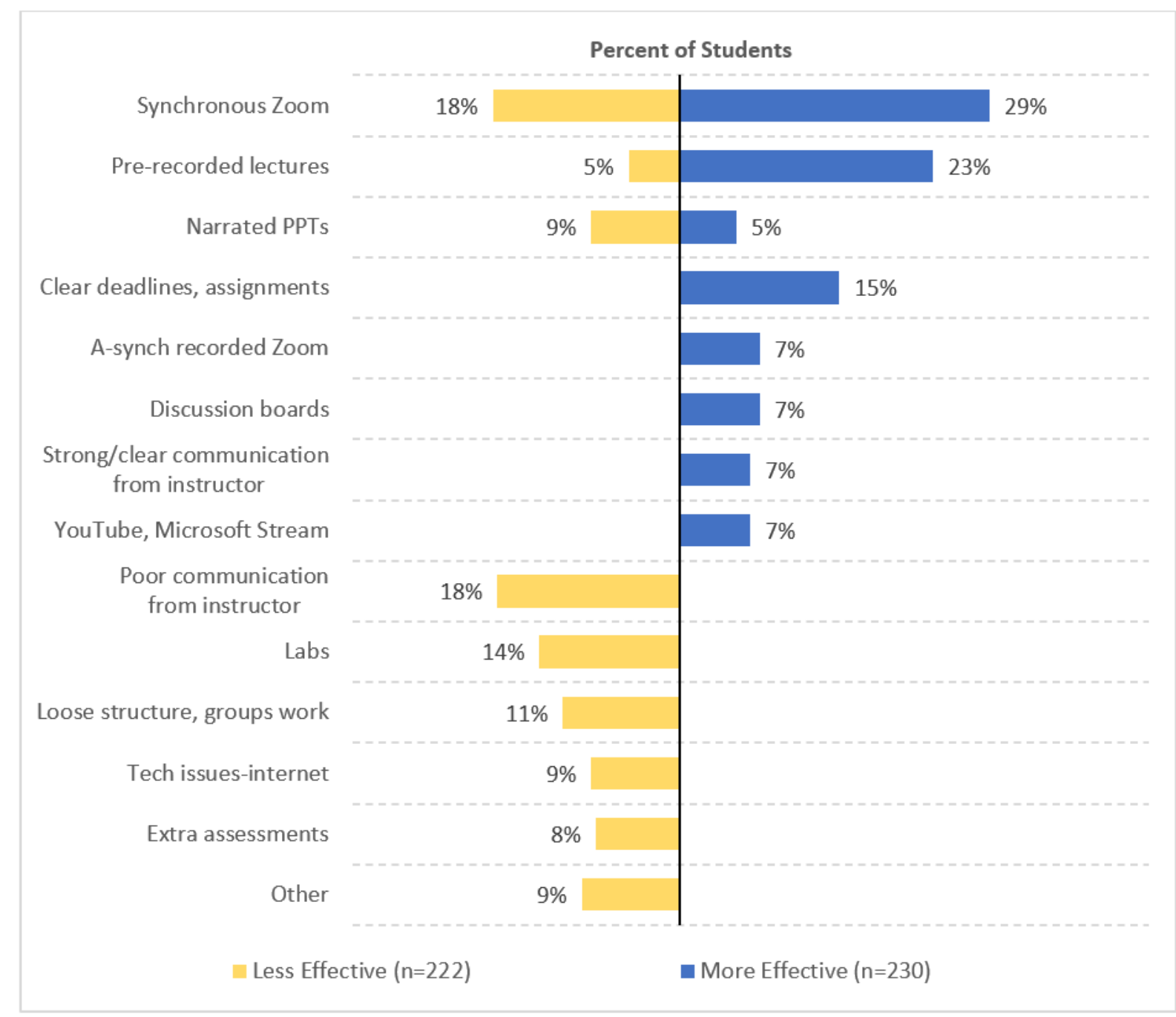

Students were adamant that the workload associated with classes should not be changed drastically, except to eliminate 'busy work' or assignments that they perceive as having a high time investment to learning value ratio. "Moving home, I have a plethora of other responsibilities to take care of... Lowering academic standards should not happen but lessening busy work should have been done in a time such as this." Pre-professional students were concerned about their level of preparation for the workforce. One respondent said, "My biggest worry is that the education I am currently getting is not the same quality of education that I would have gotten face-to-face. I am most concerned that I will become an inadequate healthcare professional." Others expressed frustration when faculty reduced content and thus the return on investment of their tuition. Students perceived the educational and financial value of online education inferior and felt those should be offered at a discount. 
Students craved structure coupled with flexibility in their courses. One student said, "The transition to online was made a lot easier when professors made their expectations clear and maintained good communication, so I felt supported and knew what I was doing." A consistent organizational structure across courses was desired so that information regarding each course could be found in the same location. Even though most universities utilize platforms such as Desire2Learn or Blackboard, significant variation in their use existed among instructors. While some students preferred the steady flow of communication via learning management systems, others felt overwhelmed by the volume of email traffic or struggled to keep up due to lack of connectivity or access to devices.

Independently motivated students thrived in transition: "I liked the independence of learning online, like the recorded lectures and [weekly] deadlines... I am pretty good with time management and was able to stay organized enough to hand in all my assignments on time." Synchronous methods were preferred by those craving social interaction since it "preserved the classroom dynamic and interaction" and by those who self-recognized a need for structure: "Online classes are my Achilles heel...but scheduled synchronous classes offered me some structure at least." Some students preferred the familiarity of the lecture setting and opted for live or recorded lectures. Seeing the professor and viewing notes and drawings made by the professor were commonly preferred to a voiced-over PowerPoint where students could hear the professor but had only slides to view. Most indicated that having recordings or notes posted enabled them to review and study better. Students craved a familiar, pre-COVID-19 approach; those from didactic courses felt disheveled if they needed to transition to more self-directed learning. Those who did not have prior experience with online learning were particularly distressed without explicit guidance: "as a new international student I am fully new to online education but most of the teachers went on as if I knew everything and that really gave me hard times understanding what was going on." Degree completion, campus connections, and hopes for face-to-face formats were the primary reasons students plan to return to SDSU in the Fall (Figure 3). While a small group highlighted COVID-19 as their top criterion for making a decision $(n=13)$, an almost equal number of students expressed their strong desire to come back to campus. This response was largely due to their negative views of online learning at home. These students mentioned lack of motivation and used words like "isolation" to describe their situation at home.

Figure 3: Factors affecting student decision to return to campus.

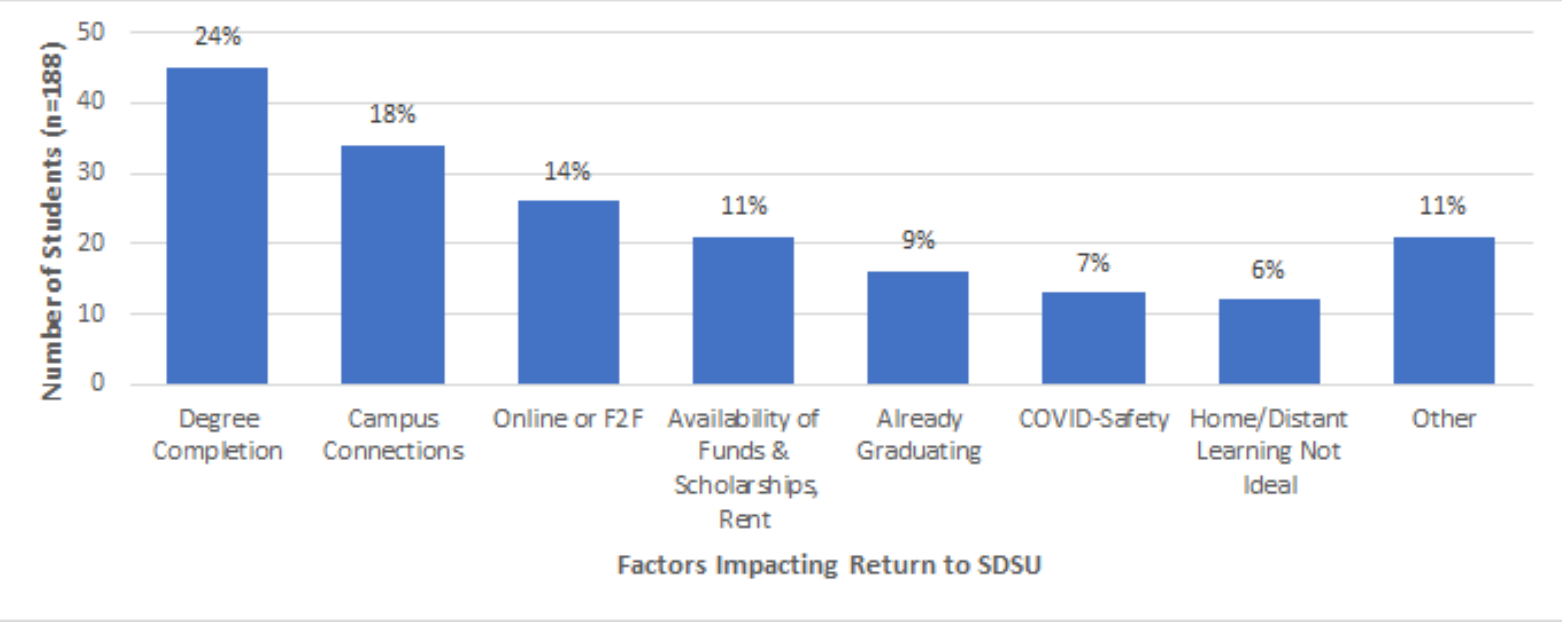




\subsection{Social and economic considerations in the COVID-19 era}

The timing of COVID-19 affected university operations during spring break. Many campuses across the US made the decision to remove students from campus housing and closed access to their campuses. Several students noted their appreciation of the process by saying, "I appreciated how SDSU used multiple platforms to inform various groups about what was going on. I am also glad that students did not come back to Brookings after spring break, as that would have brought a larger chance of spreading COVID-19 to the area." University housing returned students strategically to help minimize the risk of exposure for all stakeholders: "When moving out of the dorms, they gave us time to prepare about a week between announcing the move out schedule and the move out days beginning." Meanwhile, students were pulled into many directions. Some had to care for siblings, sick parents, and contribute to household chores. One shared: "I'm currently back with my parents and they don't understand that I have school and schoolwork ... They want me to ...clean the house and visit grandma all the time."

Figure 4: Student reflection on SDSU's response to COVID-19.

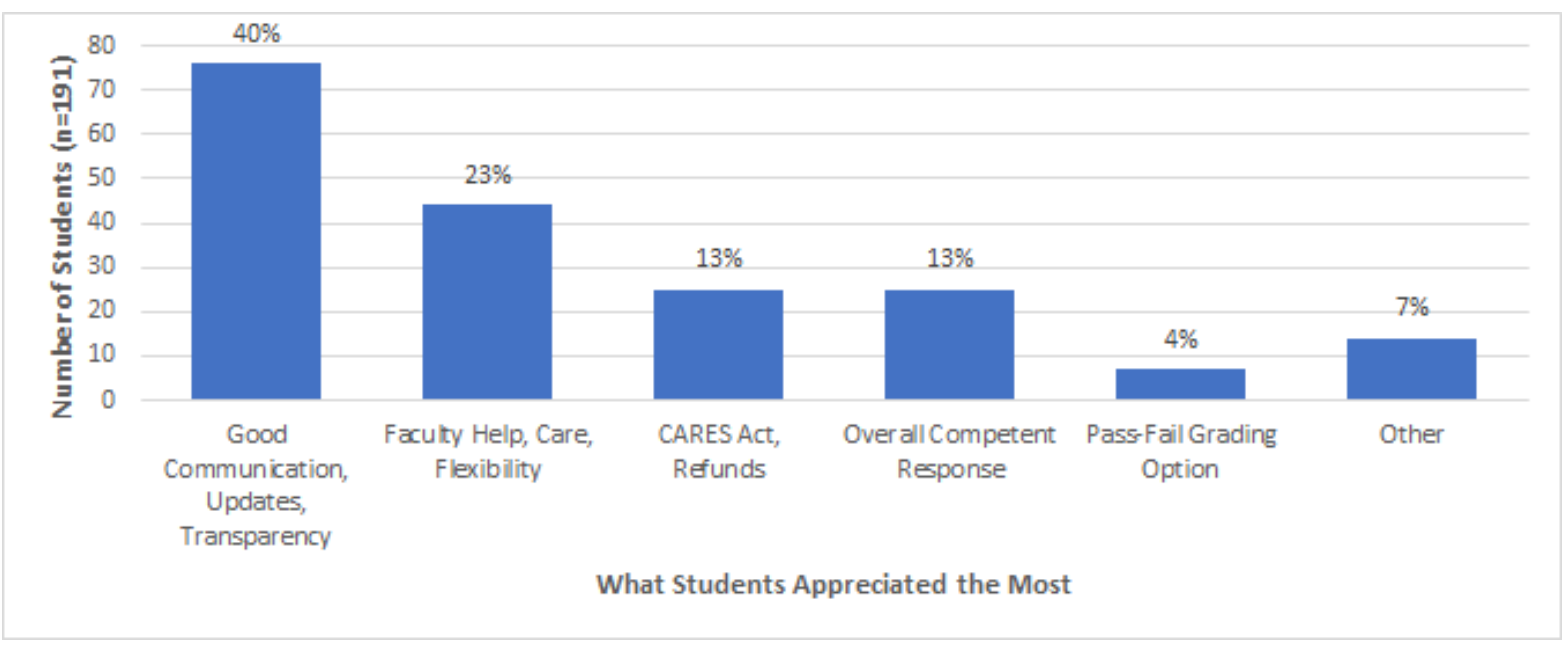

In times of uncertainty, SDSU students praised the effective communication efforts. Regular email messages and videos from the president helped them feel that the crisis was handled with transparency. Timely emails and updates from the university made students feel in the loop, well-informed, and respected. The second most frequently mentioned factor was the faculty help, support, and care. Students definitely appreciated the outreach of the faculty and the accommodations they provided (i.e. extra review sessions, more time for tests, etc.). Financial compensations and refunds were the third favorite. Students expressed appreciation for their timeliness (Figure 4).

In the coming up months, serious concerns continue to rise on the horizon. Economic issues seem to dominate the students' agenda. They worry about paying for school, having sufficient funds to cover their bills, and expenses. Finding employment during school and the job market upon graduation are frequently articulated concerns (Figure 5). After the moveout process, another key issue was how the swift transition impacted them financially, emotionally, and mentally. Many highlighted the university's ability to maintain essential services, such as counseling and dining. Adjusting to the "new normal" required new and 
creative solutions that addressed multiple issues simultaneously. Survey responses noted the importance of both flexibility and maintaining academic integrity. This quote from what students appreciated the most illustrates the intersectionality of academic, economic and health \& safety concerns: "The option for S[atisfactory]/U[nsatisfactory] grading and the move out process that adheres to social distancing rules. Also refunding for the unused housing and dining and parking."

Students who already invested multiple years into their education at SDSU were committed to staying and finishing their degrees: "SDSU has all the opportunities and open doors that I've been building the last two years. I just want it to be back to normal, but I would do anything to be back at SDSU with my wonderful professors and fellow classmates. The people are the biggest influence."

Figure 5: Reported biggest worries or concerns over the next few months for students.

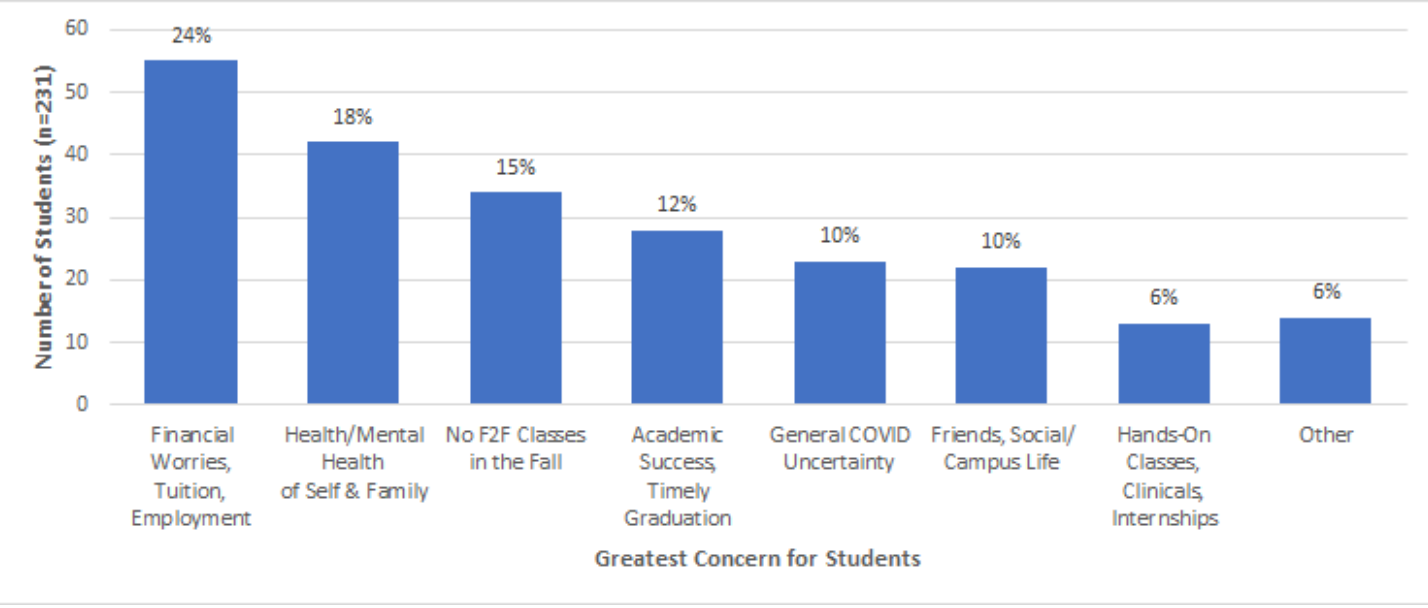

\subsection{Health and safety in the COVID-19 era}

Health issues follow the economic concerns. Students worry about large-scale spreading of the pandemic and its consequences for their health, including their mental health. Not having face-to-face classes in the Fall ranks as the third cause of worry for the students, followed by their concern about grades based on their initial experience with online learning (Figure 5). This group does not seem content about their academic performance after the sudden transitions due to COVID-19 and worry that it may negatively impact their timely graduation. General uncertainty about the progress of the COVID-19 and its negative impact on their social lives, friendships, and connections stand out among the causes of worry. Students who rely on more hands-on forms of learning such as internships, shadowing, and clinicals also express significant concern in the coming months.

Many students expressed concern for their mental health, as well as the health and safety of their family members. COVID-19 brought to light many concerns of underrepresented or marginalized communities: "My parents getting sick at work or me getting sick at work and then infecting them" illustrates the compounding nature of health problems. Students also express increased challenges to perform well academically, due to serious health problems. As noted, "I am immunocompromised, so even if others were able to return, I may not be able to, and I think it would be significantly worse to be online when everyone else is face-to- 
face than when everyone is online." They worry about a "second wave": "Whether or not it is actually safe to return to on-campus living; a residence hall is a breeding ground for such a virus and the thought of living in one now terrifies me." Students point to the abrupt changes in the academic setting compromising their mental health. For some students, the campus environment may be safer than their home environment. When asked about whether or not they would come back to SDSU next semester, one student responded: "I have nowhere else to go." At the onset of COVID-19, employment opportunities for students plummeted.

Federal regulations limited off-campus employment opportunities for international students. Some students faced serious challenges to access basic needs, including housing instability and food insecurity. These fears can lead to a mistrust of the decision makers as noted by a respondent: "... SDSU raised all of the money for the student emergency fund and we still have international students going hungry which makes me want to know where that money is truly going." Another asked a series of questions: "will I be able to get a job to pay for food and tuition for this fall, can my GPA take another semester of online classes, are my friends ok mentally, is it even safe to get a job (doesn't matter I need one), etc." The uncertainty and insecurity seemed to be an overwhelming theme as students coupled their studies with progressively lessening resources, friends, and support. Even when the university had emergency measures in place, such as the food bank on campus that provided free food to students, including international students, there is no guarantee that the information about such a relief would reach to all students in need, given the extraordinary circumstances during the pandemic.

\subsection{Honors vs. non-honors trends}

Of the 30 students who did not respond to open-ended questions, 40 percent were honors and 60percent were non-honors. When asked about their intention to return back to campus, honors and non-honors students were equally willing to return to campus in the fall. While 75 percent of the honors students stated that they would "definitely" return to campus in the fall, and another eight percent stated they would "probably" come back, for the entire sample, these percentages were 71 percent and 11 percent, respectively. In short, over 80 percent of the students we surveyed, both honors, and non-honors students, intended to continue their education at SDSU in the fall semester. The percentage of honors and non-honors students who directly supported overall themes of technology use and access, health and safety concerns, social and economic considerations, and teaching and learning are reported in Figure 6 , along with the average number of positive and negative comments made by an individual in each of the four categories. Despite reporting less financial strain than non-honors students in the quantitative portion of the survey, more honors students shared more positive comments and negative comments about social and economic considerations than non-honors students. The final question provided students with an opportunity to share any additional comments. Eighty-five percent of honors students expressed appreciation for the support of staff, 95 percent shared positive summative comments, and 85 percent shared negative summative comments. Similar populations of non-honors students shared positive summative (91 percent) and negative summative (92 percent) comments, with 78 percent expressing appreciation for staff. 
Figure 6: Percentages and posts made by honors and non-honors students in each of the four major themes: technology use and access, health and safety considerations, social and economic considerations, and teaching and learning.

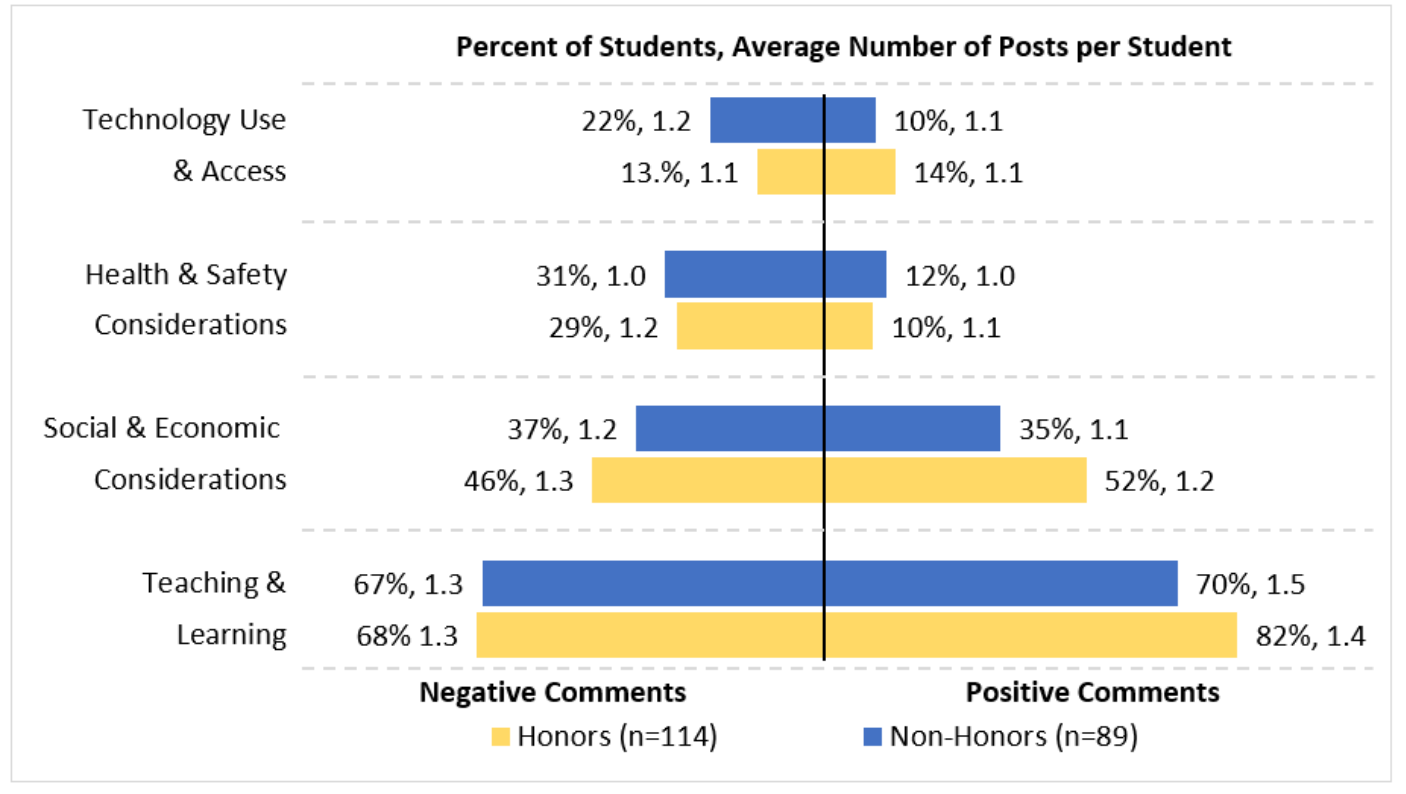

\section{Discussion}

\subsection{Characteristics of students reporting struggling academically after COVID-19}

Institutions of higher education must remain vigilant about the impact of the pandemic, particularly on the marginalized and underrepresented students. How we respond during this crisis will directly influence their future enrollment, persistence, and perception of higher education. Several broad trends were identified among students who struggled after the transition to an online environment. It is clear that these students desired improved communication. A comprehensive plan for communication from university administration, faculty, and staff could easily address this issue. These students often reported greater worry over finances, including the ability to pay bills, food, and housing. It is unclear to what extent financial problems played a role in academic success in this instance, but academic performance has long been associated with financial stress (Fosnacht \& Calderone, 2017). Continued efforts towards more scholarships, financial aid packages, and teaching personal finance may improve academic performance by relieving financial stressors.

A significant challenge for this group was accessing and utilizing technology in the online classroom environment. It is possible that students may not be able to afford technology. They may lack access to high bandwidth internet, which is a key prerequisite of strong academic performance. Potential solutions could be to continue expanding internet access particularly in rural areas, design activities and assessments that require less advanced technology, and to improve training for students on the use of instructional technology. Our results also support the need to design activities and assessments that do not exclusively rely on live or synchronous class attendance. 
Page 14 of 22

\subsection{Characteristics of honors students}

Honors students reported less worry about financial stressors and technology problems. It is not possible to accurately predict why this result was observed from our data. Honors students at SDSU had higher academic performance in secondary schools than the average student at SDSU. While financial incentives are not provided for enrolling in the Honors College, high-achieving students may have received other performance-based scholarships. Honors students could be inherently motivated and/or conditioned through honors education to approach challenges nimbly, and thus, may be more likely to successfully access and utilize instructional technology. It should be noted that the sample of respondents was not random, which could contribute to the reported differences. The survey was distributed only to students who were members of particular groups on campus: students intending to graduate with honors distinction, TRiO students, students with disabilities, and students who were enrolled in the School of American \& Global Studies. Indeed, some of the targeted groups would be more likely economically disadvantaged or first-generation college students. For example, most first-generation college students were not honors students among our respondents. Of 126 honors students, only nine were firstgeneration college students $(n=37)$.

\section{Conclusions}

Students revealed myriad factors impacting their ability to learn as well as their preferred methods of learning online. Many craved organizational structure and clear instructions from instructors while maintaining flexibility to address the additional technical, social, health, and economic related factors in their lives that had been impacted by COVID-19. Although statistically honors students faced less obstacles as a result of the transition to distance learning, they expressed similar concerns to those of non-honors students regarding their wellbeing. Despite the abrupt and drastic changes experienced this Spring, we are encouraged by this student's words: "I appreciate the fact that we didn't stop learning." Institutions of higher education must weigh both the pros and cons of creating the safest possible learning environment for all students. Based on our findings, we advocate that university administrators, faculty, and students collaborate to ensure:

1. Effective communication and social connections

2. Fiscal means for housing, food security, and tuition

3. Flexible and accessible infrastructure to support continued academic success

4. Safety of students, staff, and loved ones.

\section{Acknowledgments}

Thanks to Nadine Gjerde for contributions to survey design and distribution.

\section{References}

Al-Rabiaah, A., Temsah, M. H., Al-Eyadhy, A. A., Hasan, G. M., Al-Zamil, F., Al-Subaie, S., . . Somily, A. M. (2020). Middle east respiratory syndrome-corona virus (MERS-CoV) associated stress among medical students at a university teaching hospital in Saudi Arabia. J Infect Public Health, 13(5), 687-691. https://doi.org/10.1016/i.jiph.2020.01.005

Braun, V., \& Clarke, V. (2006). Using thematic analysis in psychology. Qualitative Research in Psychology, 3(2), 77-101. doi:10.1191/1478088706qp063oa 
Cao, W., Fang, Z., Hou, G., Han, M., Xu, X., Dong, J., \& Zheng, J. (2020). The psychological impact of the COVID-19 epidemic on college students in China. Psychiatry Res, 287, 112934. https://doi:10.1016/i.psychres.2020.112934

Fosnacht, K., \& Calderone, S. M. (2017). Undergraduate financial stress, financial selfefficacy, and major choice: a multi-institutional study. Journal of Financial Therapy, 8(1) 7. Retrieved from https://doi.org/10.4148/1944-9771.1129

Hodges, C., Moore, S., Lockee, B., Trust, T., \& Bond, A. (2020). The difference between emergency remote teaching and online learning. Educause Review. Retrieved from https://medicine.hofstra.edu/pdf/faculty/facdev/facdev-article.pdf

Linneberg, M. S., \& Korsgaard, S. (2019). Coding qualitative data: a synthesis guiding the novice. Qualitative Research Journal, 19(3), 259-270. Retrieved from https://doi.org/10.1108/QRJ-12-2018-0012

Nightingale, B. (2014). Teaching honors online at a public college. Journal of the National Collegiate Honors Council--Online Archive, 15(Spring/Summer 2014). Retrieved from https://digitalcommons.unl.edu/nchcjournal/425/

Pham, S. (2017). Addressing common mental health issues prevalent among honors college students. Western Michigan University, Retrieved from

https://scholarworks.wmich.edu/cgi/viewcontent.cgi?article=3904\&context=honors theses

Wall, K. (2020). COVID-19 pandemic: impacts on the work placements of postsecondary students in Canada. In (pp. [6] p.). Ottawa: Statistics Canada. Retrieved from https://www150.statcan.gc.ca/n1/pub/45-28-0001/2020001/article/00022-eng.htm

Zhai, Y., \& Du, X. (2020). Addressing collegiate mental health amid COVID-19 pandemic. Psychiatry Research, 288, 113003. https://doi:10.1016/i.psychres.2020.113003

Zubizarreta, J. (2020). Using the online forum for honors learning. Honors in Practice -Online Archive, 16, 216-218. Retrieved from https://digitalcommons.unl.edu/cgi/viewcontent.cgi?article=1325\&context=nchchip 
Appendix A. Survey questionnaire distributed to students for data collection.

SDSU Student Survey RE COVID-19

Contributors: SOS - Support Our Students Network, Honors Faculty, CETL Faculty Fellows

Objectives

1. Identify factors which enhanced/detracted from student learning during COVID-19

2. Determine whether students continue to feel connected to SDSU

3. Ascertain circumstances which may impact students' ability to learn effectively during COVID-19

Dear Students,

We know this spring has been challenging for everyone at South Dakota State University. We're sending this survey to check in and see how you're doing. We want to know how you feel about our response to COVID-19 and if there are things we can do to help you. We'd also like to know about your experiences with various methods of online instruction this term.

Your participation in this survey is completely voluntary. There are no penalties if you decide not to participate or if you choose to skip any questions. The survey has 27 questions ( 22 substantive and 5 demographic) and should take 10-20 minutes to complete. It is very important for us to learn your opinions. We anticipate no risks taking this survey.

Your responses will be strictly confidential and data from this survey will be reported only in the aggregate. No one will be able to link your responses to your name or other information that might identify you. This survey has been adapted with permission from the (C) 2020 Higher Education Data Sharing Consortium.

SDSU SOS - Support Our Students Network, Honors Faculty, and Center for Excellence in Teaching \& Learning (CETL) Faculty Fellows collaborated for this Survey. If you have questions at any time about the survey or the procedures, you may contact Dean Rebecca $C$. Bott-Knutson at 605-688-5268 or by email Rebecca.Bott@sdstate.edu

We would appreciate hearing from you so we can get a better sense of how you're doing and ways that we can help. Thank you for your time.

1. Please indicate your level of agreement with each of the following statements SDSU. Use responses: Strongly agree, Agree, Neither agree nor disagree, Disagree, Strongly disagree

- Overall, staff and administration at SDSU have shown care and concern for me as they respond to the spread of COVID-19.

- Overall, faculty at SDSU have shown care and concern for me as they make changes in their courses in response to COVID-19.

- I know people who I may contact if I have questions about how changes at SDSU in response to COVID-19 will affect my educational plans.

- I felt as though I was struggling academically before spring break.

- I felt as though I have been struggling academically since spring break.

2. Please indicate your level of satisfaction with SDSU about the following: 
Use responses: Very satisfied, Generally satisfied, Neither satisfied nor dissatisfied, Generally dissatisfied, Very dissatisfied

- The support you are getting from SDSU to help you transition to taking your classes online

- The communication you are getting from SDSU about its ongoing responses to COVID-19

- The information you are getting about how changes at SDSU in response to COVID-19 will impact your ability to pay for college (e.g., financial aid, student loans, campus jobs)

3. Do you have reliable internet access during regular work hours?

Use Responses: Yes, I have very good internet access; Yes, I have internet access, but it is limited; My only internet access is through my phone; No, I don't have internet access; Other, please explain

4. Given the changes at SDSU caused by the spread of COVID-19, how often do you worry about the following?

Use responses: Never, Almost never, Sometimes, Often, Very Often

- Doing well in college now that many or all of your classes are online

- Losing friendships and social connections now that classes are online

- Accessing and successfully using the technology needed for your online classes

- Having access to health care

- Paying your bills (e.g., tuition, loans, rent, internet access, medical)

- Having a safe and secure place to sleep every night

- Having enough to eat day-to-day

5. Can you describe your use of the following learning supports before and after COVID19 ?

Use Responses: I used this before COVID, I am using this after COVID, Never used this service, Prefer not to answer

- SDSU Counseling Services

- Tutoring Services

- SDSU Writing Center

- SDSU Office of Disability Services

- SDSU Testing Center

- SDSU Briggs Library online services

In this section of the survey, we want to explore your experiences with various methods of online instruction. These might include viewing videos online, using online discussion boards, doing quizzes and tests online, live group discussions on Zoom or other conferencing software, online narrated PowerPoint lectures, interactive simulations, virtual office hours, collaborative group project tools, virtual tutoring centers, online library materials, etc. We will use this information to improve our online courses. We appreciate your taking the time to tell us what's helpful and what's not.

6. Please identify whether each style of course was more challenging face to face, more challenging online, or equally challenging: 
- Courses with a lab component

- Courses that require hands on learning (i.e. fieldwork, site visits, equipment use, etc.)

- Courses that have group/team projects

- Larger, lower division courses (i.e. SGR courses with 100 or more students)

- Smaller, upper division courses

- Courses that relied more heavily on discussion and participation

7. How comfortable are you with using Zoom as part of your learning experience? Use Responses: Very Uncomfortable, Uncomfortable, Neutral, Comfortable, Very Comfortable

8. Did you experience any of the following technology access barriers during remote learning in response to COVID-19?

Use Responses: Never, Once in a while, About half the time, Most of the time, Always

- D2L/Zoom/Other Learning Website not working properly

- Course Content/Materials not in an Accessible Format for Disability

- Having the right technology to complete assigned work (i.e. computer camera, etc.)

- Sharing Device with others in household

- Ability to scan or print necessary course materials

- Participate in live/synchronous class activities due to other obligations

9. When the courses switched to online which of these online instructional methods have worked best for you, and why?

Response: open-ended

10. Of the online instructional methods that you have experienced, which ones have not worked well for you? Why do you think they were not effective?

Response: open-ended

11.Please answer the following questions by using the slider from 0 (minimum) to 10 (maximum)

- In general, how much do you prefer face-to-face classes?

- In general, how much do you prefer all online classes?

- How much do you prefer hybrid (part face-to-face, part online) classes?

This section has questions about your general well-being.

12. Overall, how much stress are you feeling about the potential consequences of the spread of COVID-19?

Little or none

Some

A great deal

13. How did the COVID-19 crisis impact the time you spend on the following tasks? Use Responses: Less time spent now, Same time as before COVID, More time spent now

- Studying for your courses

- Paid work, employment

- Household duties or care of family members

- Help with family business (farm, ranch, etc.) 
- Social time with friends

14. How connected do you feel to SDSU?

More connected than before COVID

Equally connected before/after COVID

Less connected after COVID

15. Do you feel that your current level of connection is appropriate for the circumstances?

Yes

No

16. Do you intend to return to SDSU next fall to continue and/or complete your education?

Definitely yes

Probably yes

Probably no

Definitely no

Unsure

Not applicable, because I am graduating

17. What factor is having the biggest influence on your thoughts about whether or not to return to SDSU next fall?

Response: open-ended

18. What have you appreciated most about SDSU's response to COVID-19?

Response: open-ended

19. What are your biggest worries or concerns as you think about what's coming up in the next few months?

Response: open-ended

20. Since the COVID-19 changes at SDSU, where have you spent most of your time living?

Use responses:

Dormitory or other campus housing (not a fraternity or sorority house)

Fraternity or sorority house (including college-owned housing)

Residence (house, apartment, etc.) within walking distance to campus

Residence (house, apartment, etc.) farther than walking distance to your institution In another country

A living arrangement not listed above

21. What is your college classification for the 2019-2020 academic year?

Freshman/First Year

Sophomore

Junior

Senior

Graduate Student

Other:

22. Is there anything else you'd like to tell SDSU about the way we've responded to COVID-

19 and your experience this spring?

Response: open-ended 
GENDER: What is your gender?

Man

Woman

Non-binary, please specify:

CITIZENSHIP: What is your citizenship status?

U.S. citizen

U.S. permanent resident but not a U.S. citizen

Not a U.S. citizen or permanent resident

HISPANIC: Are you Hispanic or Latino/a?

Yes

No

RACE: Please indicate the race or races with which you identify. (Choose one or more) American Indian or Alaska Native Asian

Black or African American

Native Hawaiian or Pacific Islander

White

HONORS: Please check all the group affiliations that apply to you:

Planning to graduate with Honors College Distinction

TRiO participant

Student with a Disability

International Student

Student Athlete

First Generation College Student

Enrolled in School of American \& Global Studies

Prefer not to answer 
Appendix B. Comparison of students who self-reported as 1) not struggling academically before and after the transition to online classes $(n=123)$ and 2) not struggling academically before the transition to online classes but struggling academically after ( $n=99)$.

\begin{tabular}{|c|c|c|c|c|}
\hline Question: & $\begin{array}{l}\text { Not } \\
\text { Struggling }\end{array}$ & $\begin{array}{l}\text { Struggling } \\
\text { After COVID- } \\
19^{1}\end{array}$ & t-test & $P^{2}$ \\
\hline $\begin{array}{l}\text { Overall, faculty at SDSU have shown } \\
\text { care and concern for me as they make } \\
\text { changes in their courses in response to } \\
\text { COVID-19. }{ }^{3}\end{array}$ & 4.17 & 3.69 & 4.12 & $<0.0001^{+}$ \\
\hline $\begin{array}{l}\text { How satisfied are you with the support } \\
\text { you are getting from SDSU to help you } \\
\text { transition to taking your classes online? } \\
4\end{array}$ & 3.88 & 3.22 & 5.75 & $<0.0001^{\dagger}$ \\
\hline $\begin{array}{l}\text { How often do you worry about paying } \\
\text { your bills? } 5\end{array}$ & 2.11 & 3.04 & 5.44 & $<0.0001^{+}$ \\
\hline $\begin{array}{l}\text { Participate in live/synchronous class } \\
\text { activities due to other obligations. }{ }^{5}\end{array}$ & 1.97 & 2.83 & 5.48 & $<0.0001^{\dagger}$ \\
\hline $\begin{array}{l}\text { Having the right technology to complete } \\
\text { assigned work. }{ }^{5}\end{array}$ & 1.51 & 1.80 & 2.21 & 0.0284 \\
\hline $\begin{array}{l}\text { Sharing device with others in household. } \\
5\end{array}$ & 1.36 & 1.70 & 2.60 & 0.0103 \\
\hline $\begin{array}{l}\text { How often do you worry about having } \\
\text { course content and materials provided } \\
\text { in a disability accessible format? }{ }^{5}\end{array}$ & 1.46 & 1.95 & 3.23 & 0.0015 \\
\hline $\begin{array}{l}\text { D2L/Zoom/Other learning website not } \\
\text { working properly. }{ }^{5}\end{array}$ & 1.85 & 2.12 & 2.87 & 0.0045 \\
\hline $\begin{array}{l}\text { Overall, staff and administration at } \\
\text { SDSU have shown care and concern for } \\
\text { me as they respond to the spread of } \\
\text { COVID-19. }{ }^{3}\end{array}$ & 4.30 & 3.93 & 3.47 & $0.0006^{+}$ \\
\hline $\begin{array}{l}\text { Do you feel that your current level of } \\
\text { connection is appropriate for the } \\
\text { circumstances? }{ }^{6}\end{array}$ & 1.09 & 1.24 & 2.84 & 0.0052 \\
\hline $\begin{array}{l}\text { Do you have reliable internet access } \\
\text { during regular work hours? }{ }^{7}\end{array}$ & 1.41 & 1.65 & 2.59 & 0.0104 \\
\hline $\begin{array}{l}\text { How satisfied are you with the } \\
\text { communication you are getting from } \\
\text { SDSU about its ongoing responses to } \\
\text { COVID-19? }{ }^{4}\end{array}$ & 4.11 & 3.73 & 3.28 & $0.0013^{+}$ \\
\hline $\begin{array}{l}\text { How the COVID- } 19 \text { crisis impacted time } \\
\text { spent studying for courses. }{ }^{8}\end{array}$ & 1.85 & 1.60 & 2.08 & 0.0388 \\
\hline $\begin{array}{l}\text { I know people who I may contact if I } \\
\text { have questions about how COVID-19 }\end{array}$ & 3.85 & 3.54 & 2.40 & 0.0175 \\
\hline
\end{tabular}




\begin{tabular}{|c|c|c|c|c|}
\hline $\begin{array}{l}\text { related changes at SDSU will affect my } \\
\text { educational plans. }{ }^{3}\end{array}$ & & & & \\
\hline $\begin{array}{l}\text { How often do you worry about } \\
\text { accessing and successfully using the } \\
\text { technology needed for your online } \\
\text { classes? } 5\end{array}$ & 1.96 & 2.60 & 4.21 & $<0.0001^{+}$ \\
\hline $\begin{array}{l}\text { How often do you worry about having a } \\
\text { safe and secure place to sleep every } \\
\text { night? }{ }^{5}\end{array}$ & 1.27 & 1.65 & 2.45 & 0.0154 \\
\hline $\begin{array}{l}\text { How often do you worry about having } \\
\text { enough to eat day-to-day? }{ }^{5}\end{array}$ & 1.33 & 1.77 & 2.86 & 0.0048 \\
\hline $\begin{array}{l}\text { How comfortable are you with using } \\
\text { Zoom as part of your learning } \\
\text { experience? }{ }^{9}\end{array}$ & 3.88 & 3.30 & 4.10 & $<0.0001^{\dagger}$ \\
\hline $\begin{array}{l}\text { How satisfied are you with the } \\
\text { information you are getting about how } \\
\text { changes at SDSU in response to COVID- } \\
19 \text { will impact your ability to pay for } \\
\text { college? }{ }^{4}\end{array}$ & 3.65 & 3.09 & 3.97 & $0.0001^{\dagger}$ \\
\hline $\begin{array}{l}\text { Ability to scan or print necessary course } \\
\text { materials. }{ }^{5}\end{array}$ & 1.86 & 2.67 & 4.46 & $<0.0001^{+}$ \\
\hline $\begin{array}{l}\text { How often do you worry about doing } \\
\text { well in college now that many or all of } \\
\text { your classes are online? }{ }^{5}\end{array}$ & 2.54 & 3.99 & 11.83 & $<0.0001^{\dagger}$ \\
\hline $\begin{array}{l}\text { How often do you worry about losing } \\
\text { friendships or social connections now } \\
\text { that many or all of your classes are } \\
\text { online? } 5\end{array}$ & 2.78 & 3.26 & 2.95 & 0.0035 \\
\hline $\begin{array}{l}\text { How often do you worry about having } \\
\text { access to healthcare? }{ }^{5}\end{array}$ & 1.46 & 2.21 & 4.76 & $<0.0001^{\dagger}$ \\
\hline $\begin{array}{l}\text { Are smaller, upper-level classes more } \\
\text { challenging face-to-face or online? }{ }^{10}\end{array}$ & 2.34 & 2.53 & 2.19 & 0.0294 \\
\hline
\end{tabular}

1 "Not Struggling" was defined as students who reported not struggling academically before or after transition to online classes and "Struggling After COVID-19" was defined as students who reported only struggling after the transition to online classes.

${ }^{2}$ Only responses exceeding nominal significance level of $P<0.05$ reported; ${ }^{\dagger}=$ Bonferroni $P<0.0014(\mathrm{n}=37)$.

${ }^{3}$ Responses coded as 1 = strongly disagree, 2 = disagree, $3=$ neutral, $4=$ agree, and $5=$ strongly agree.

${ }^{4}$ Responses coded as 1 = very dissatisfied, 2 = not satisfied, 3 = neutral, 4 = satisfied, and 5 = very satisfied.

${ }^{5}$ Responses coded as $1=$ never, $2=$ once in a while, $3=$ about half the time, $4=$ most of the time, and $5=$ always.

${ }^{6}$ Responses coded as 1 = yes, 2 = no.

${ }^{7}$ Responses coded as 1 = good access, 2 = somewhat limited access, 3 = only through my phone, $4=$ no access.

${ }^{8}$ Responses coded as $1=$ less time, 2 = same amount of time, and $3=$ more time.

${ }^{9}$ Responses coded as 1 = very uncomfortable, $2=$ uncomfortable, $3=$ neutral, $4=$ comfortable, and $5=$ very comfortable.

${ }^{10}$ Responses coded as 1 = more challenging face-to-face, 2 = equally challenging in either format, and $3=$ more challenging online. 